\title{
Factors affecting selection of resting site type by pine marten in primeval deciduous forests (Białowieża National Park, Poland)
}

\author{
Andrzej ZALEWSKI
}

Zalewski A. 1997. Factors affecting selection of resting site type by pine marten in primeval deciduous forests (Białowieża National Park, Poland). Acta Theriologica 42: 271-288.

The resting site choice of 14 pine martens Martes martes (Linnaeus, 1758) (6 males and 8 females) in Białowieża National Park (BNP), north-eastern Poland, was analysed. The radio-collared martens were located 1,790 times in 877 different resting sites. For both males and females, arboreal resting sites (cavity and nest) constituted over $95 \%$ of the resting events. Cavities were used more frequently than nests. Resting site use differed significantly between sexes and seasons. Females rested in nests less often than males (especially in spring), but selected cavities more frequently than did males. Females with young chose only cavities, whereas non-breeding females often rested in nests. Weather conditions influenced the choice of resting sites in various months. For males, temperature was a significant factor from October to May, for females from December to March and in June-July. Martens rested in nests when mean ambient temperatures were higher, in cavities or on the ground when temperatures were lower. In summer and winter, when average humidity was high males often rested in cavities or places on the ground. When winds were strong or snow cover was deep, martens chose ground sites. In years of high squirrel density, frequency of nest use by marten increased. During severe winters, frequency of use of ground sites increased. Oak, lime, and spruce trees were frequently used by martens (males $-85.7 \%$ and female $-70.6 \%$ of all resting sites). Males rested in spruce more often than females, while females used oak and lime more often than males. Martens selected lime and oak, and avoided hornbeam trees. Literature on winter resting sites of pine martens in Europe was reviewed. It was shown that in northern Europe martens rested primarily on the ground. In the temperate zone, martens used cavities in trees (eastern Europe) on nests (western Europe).

Mammal Research Institute, Polish Academy of Sciences, 17-230 Białowieża, Poland; e-mail: zalewski@bison.zbs.bialowieza.pl

Key words: Martes martes, resting site selection, radio-telemetry, weather factors, tree species selection

\section{Introduction}

Most marten species have adapted in an unorthodox pattern to cold regions. They have a limited reserve of body fat in winter (Ocetkiewicz 1973, Buskirk and Harlow 1989, Korhonen et al. 1995), the fur is not exceptionally insulative (Scholander et al. 1950), they have long body that increases heat loss (Iversen 1972), and are 
active throughout the winter (Zielinski et al. 1983, Marchesi 1989). Additionally, in winter, ambient temperatures are lower than $0^{\circ} \mathrm{C}$ in a large part of the martens' range. One adaptation to the cold environment is an ability to depress the body temperature during resting. For example, American martens Martes americana are able to depress their body temperature on average by $2.9^{\circ} \mathrm{C}$ (Buskirk et al. 1988). Other adaptations are changes in activity pattern and hunting on bigger prey in winter (Zielinski et al. 1983, Thompson and Colgan 1991). Both European and American martens tend to choose better insulated resting sites during spells of low temperature, often subnivean sites associated with coarse woody debris (Buskirk et al. 1989, Marchesi 1989, Brainerd et al. 1995).

On the other hand, most martens as medium-size animals, can be killed by larger predators (Lindström et al. 1995, Okarma et al. 1997). The risk of predation should have a strong influence on the selection of resting sites by martens. They may select sites high in trees to minimize exposure to ground predators. Thus, they need resting sites of different structures in various situations.

The European pine marten Martes martes (Linnaeus, 1758) use variety of structures including tree cavities, burrows, birds and squirrel nests, piles of logged timber or artificial nest boxes (Pulliainen 1981, Baudvin et al. 1985, Marchesi 1989, Baranauskas 1990, Brainerd et al. 1995, Stier 1996). Most records of resting sites are simple descriptions of resting site types, often of small number (Nasimovich 1948, Novikov et al. 1970, Danilov and Tumanov 1976, Stier 1996), although a few studies have examined factors affecting choice of resting sites type (Marchesi 1989, Brainerd et al. 1995) and choice of tree species (Stier 1996). Furthermore, most of those studies were done in boreal coniferous forests (Nasimovich 1948, Pulliainen 1981, Brainerd et al. 1995) or mountain forests (Ryabov 1959, Marchesi 1989) but not in deciduous forests.

The pine marten occurs across almost the whole of Europe (Grakov 1981, Corbert and Harris 1991), inhabiting northern boreal forests as well as southern temperate deciduous forests. Historically, a large portion of the range of pine marten was covered by deciduous forests. In such pristine forests, marten had access to many old deciduous trees with cavities, and to much coarse woody debris. But most of the deciduous woodland in Europe have been deforested and their natural characteristics changed (Okarma 1995).

This study of resting site choice by pine martens was carried out in the last remnant of pristine deciduous and mixed forest of the European lowlands. The study site provided an unique opportunity to investigate the nearly pristine relationship between martens and their habitat. The geographical localization of the study area in north-eastern Poland provided the possibility of analysing the impact of severe winters and warm summers on resting site choice.

In this paper I analysed: (1) seasonal and among-year variation in resting site use by male and female pine martens, (2) influence of climatic factors on resting site choice, and (3) selection of tree species for resting in the deciduous and mixed forests. 


\section{Study area}

Field work was conducted in 1991-1996 in Białowieża National Park (BNP; $52^{\circ} 43^{\prime} \mathrm{N}, 23^{\circ} 54^{\prime} \mathrm{E}$ ) in north-eastern Poland. BNP covers $47.5 \mathrm{~km}^{2}$ and is a part of extensive forest complex of Białowieża Primeval Forest $\left(1,250 \mathrm{~km}^{2}\right.$, Polish and Byelorussian parts). The structure and character of BNP is typical of primeval forests and includes rich, mature stands dominated by oak Quercus robur, hornbeam Carpinus betulus, lime Tilia cordata, with admixtures of spruce Picea abies. Alderwoods, dominated by black alder Alnus glutinosa, grow in wet areas. Flood-plain forests, located in the vicinities of small forest rivers, are composed of ash Fraxinus excelsior, black alder, elm Ulmus glabra and spruce. There are mixed coniferous stands with spruce and pine Pinus silvestris on sandy soils. Regeneration and growth of saplings takes place under the canopy of old trees. The average age of all tree stands was 130 years. Detailed description of the BNP is given in Faliński (1986) and Sokolowski (1993).

The climate of BNP is transitional in character, but continental features prevail (Olszewski 1986). From April 1991 throughout March 1996, the coldest month was either January or February and average daily temperature for these two months varied in consecutive years as follows: January: -1.6 , $-0.9,1.1,-3.1,-8.5^{\circ} \mathrm{C}$; February: $-0.3,-2.1,-5.0,2.2,-7.0^{\circ} \mathrm{C}$. The warmest month was July and average temperature varied from 16.8 to $22.5^{\circ} \mathrm{C}$ (highest day temperature was $28.7^{\circ} \mathrm{C}$ ). Maximum recorded snow depth was $63 \mathrm{~cm}$ (in the winter of 1995/96).

\section{Material and methods}

Between April 1991 and March 1996 pine martens Martes martes were captured with live box traps (baited with eggs, honey, or meat in different seasons). Each marten was anaesthetised with Ketalar and fitted with a radio-transmitter (AVM 12-15 g or Lotek $25 \mathrm{~g}$ ). Age class was determined by comparing tooth wear. All individuals except 2 males (M5 and M7) were older than 1 year. Martens were sexed and released at the site of capture. Fourteen martens ( 6 males and 8 females) were monitored in the daylight hours (mostly between 07.00 and $14.00 \mathrm{~h}$ ), when the animals were generally inactive (A. Zalewski, unpubl.). They were located 1,790 times in 877 different sites (see Zalewski 1997 , for a full list of radiotracked animals).

Martens were found in four types of resting sites: (1) tree cavities located higher than $0.5 \mathrm{~m}$ above ground, (2) nests (bird nests or squirrel dreys), (3) branches in the tree crown, and (4) on the ground $(0-0.5 \mathrm{~m}$ above ground, in cavities at the bases of trees, in fallen logs or in burrows between tree roots). In 109 cases, identification of type of resting site was not possible because both nests and cavities were located on the same tree, or two trees grew in a too close proximity to differentiate. In the first case, only tree species was recorded. All resting sites were marked with a tape on which the date and identity number of an individual were noted.

I obtained the following weather data from the Białowieża Meteorological Station: ambient temperature $\left({ }^{\circ} \mathrm{C}\right)$, humidity $(\%)$, wind speed $(\mathrm{m} / \mathrm{s})$, and snow cover depth $(\mathrm{cm})$. All measurements of weather conditions were made in the morning (07.00) after martens had usually ceased activity and selected a resting site (A. Zalewski, unpubl.). The weather station was located in the woodland park $2 \mathrm{~km}$ distant from the study area and measurements from the station correlated linearly with those from within BNP (Olszewski 1986).

I calculated selectivity of tree species by martens in two scales: landscape (the whole BNP, ca 50 $\mathrm{km}^{2}$ ) and individual home range $\left(2 \mathrm{~km}^{2}\right.$, on average). The diameter at breast height (dbh) of 349 trees in the areas of the marten resting sites was measured. In order to calculate tree selectivity at both scales, only trees with a sufficient dbh for a marten resting site were used (ie bigger than the minimum size of tree found with the marten's resting site): $>10 \mathrm{~cm}$ for spruce, $>35 \mathrm{~cm}$ for hornbeam and $>40 \mathrm{~cm}$ for other species. Fourteen forest types in Białowieża National Park were distinguished (Sokołowski 1993) and average numbers per 1 hectare of sufficiently large trees, of each species, in 
each forest community were calculated from 59 plots (mean plot area size $=0.862$ ha) (Forest Management Plan of the Białowieża National Park 1992). At the landscape scale, percentage composition of forest types in the National Park (Forest Management Plan of the Białowieża National Park 1992) were used for calculation of percentage composition of sufficient trees in BNP. At the home range scale, tree species compositions for marten home ranges were calculated only for these individuals which were relocated more than 25 times in different resting sites in each season. For males M3, M4 and M5, and female F6, the data on choice of tree species during the same seasons of different years were combined. In any season, home ranges were calculated by using all localizations $(>100)$ in continuous tracking sessions at 15-minutes interval when a marten was active and once during inactivity period. Home range was calculated by the minimum convex polygon method (Tracker computer program). All home ranges were printed on the Forest Communities map (1:20000; Sokołowski 1993), and percentage of each community in each home range was calculated using a planimeter. Selectivity of tree species was calculated by Ivlev's electivity index (Jacobs 1974). In both scales, selectivity of tree species by martens was calculated only for trees that composed $>2 \%$ of the tree stand. I analysed data in the following seasons: spring (16 March - 15 June), summer (16 June - 15 October) and autumn-winter (16 October - 15 March).

\section{Results}

\section{Types of resting sites used by pine marten}

Arboreal sites (mainly cavity and nest) were used most often throughout the year, constituting $>95 \%$ of the resting episodes (Table 1). Of these types of resting sites, martens used cavities more frequently than nests in the whole year ( $G$-test: $G=7.8, \mathrm{df}=1, p<0.01)$, and autumn-winter $(G=23.3, \mathrm{df}=1, p<0.001)$. In spring and summer, martens used cavities and nests in approximately the same proportion $(G=1.3$ and $G=2.4$ respectively, $\mathrm{df}=1, \mathrm{~ns})$. Significant variation in use of resting sites occurred between sexes in all seasons $\left(\chi^{2} \geq 23.2, \mathrm{df}=3, p<0.001\right)$ and when data were combined for whole year $\left(\chi^{2}=136.9\right.$, $\left.\mathrm{df}=3, p<0.0001\right)$. On an annual basis, females rested in nests less often than males $(19.3 \%$ versus $47.8 \%, G=12.5$, $\mathrm{df}=1, p<0.001)$ but selected cavities more frequently than males $(75.8 \%$ versus $44.9 \%, G=8.0, \mathrm{df}=1, p<0.001)$. Male and female martens showed the significant seasonal variation in selection of resting sites $\left(\chi^{2} \geq 15.7, \mathrm{df}=3, p<0.005\right)$. The only exception was during spring and summer when females chose cavities for the natal dens $\left(\chi^{2}=4.2, \mathrm{df}=3\right.$, ns; Table 1$)$.

When analysed on a monthly basis, males appeared to increase their use of nests from January to May, then decrease it till July, and to increase slightly in August and September (Fig. 1). Females often used nests in March, July and August. From April to October, both males and females sometimes rested on the branches. From October to April martens occasionally chose resting sites on the ground (Fig. 1). In BNP martens did not rest under the snow.

The selection of resting site type was different for females with young than for non-breeding females $\left(\chi^{2}=60.3, \mathrm{df}=2, p<0.001\right.$ ) (Fig. 2). Females with young most often chose cavities, whereas non-breeding females frequently rested in nests. Males rested in nests significantly more often during this period than did females 
Table 1. Resting sites used by pine martens in different seasons and during the whole year in Białowieża National Park, in 1991-1996. $n$ - number of observation, W\% - weighted mean with regard to the number of days in each season: spring - 16 March to 15 June (92 days), summer - 16 June to 15 October (122 days) and autumn-winter - 16 October to 15 March (151 days).

\begin{tabular}{|c|c|c|c|c|c|c|c|}
\hline \multirow{2}{*}{$\begin{array}{l}\text { Resting } \\
\text { site type }\end{array}$} & \multicolumn{2}{|c|}{ Spring } & \multicolumn{2}{|c|}{ Summer } & \multicolumn{2}{|c|}{ Autumn-winter } & \multirow{2}{*}{$\begin{array}{c}\text { Whole year } \\
\text { W\% }\end{array}$} \\
\hline & $n$ & $\%$ & $n$ & $\%$ & $n$ & $\%$ & \\
\hline \multicolumn{8}{|c|}{ Males } \\
\hline Cavity & 66 & 31.1 & 108 & 40.2 & 350 & 57.0 & 44.9 \\
\hline Nest & 138 & 65.1 & 133 & 49.4 & 221 & 36.0 & 47.8 \\
\hline Branch & 8 & 3.8 & 24 & 8.9 & 8 & 1.3 & 4.5 \\
\hline On the ground & 0 & 0 & 4 & 1.5 & 35 & 5.7 & 2.8 \\
\hline Total & 212 & 100 & 269 & 100 & 614 & 100 & 100 \\
\hline \multicolumn{8}{|c|}{ Females } \\
\hline Cavity & 188 & 75.8 & 69 & 67.7 & 194 & 82.2 & 75.8 \\
\hline Nest & 48 & 19.4 & 29 & 28.4 & 28 & 11.9 & 19.3 \\
\hline Branch & 10 & 4.0 & 4 & 3.9 & 0 & 0 & 2.3 \\
\hline On the ground & 2 & 0.8 & 0 & 0 & 14 & 5.9 & 2.6 \\
\hline Total & 248 & 100 & 102 & 100 & 236 & 100 & 100 \\
\hline \multicolumn{8}{|c|}{ Males and females pooled (averaged percentages) } \\
\hline Cavity & & 53.5 & & 53.9 & & 69.6 & 60.4 \\
\hline Nest & & 42.2 & & 38.9 & & 23.9 & 33.5 \\
\hline Branch & & 3.9 & & 6.4 & & 0.7 & 3.4 \\
\hline On the ground & & 0.4 & & 0.8 & & 5.8 & 2.7 \\
\hline
\end{tabular}

ก $126,142,110,64,76,66,75,74,44,103,101,114 \quad$ ก $57,43,84,79,100,37,34,23,18,30,37,44$
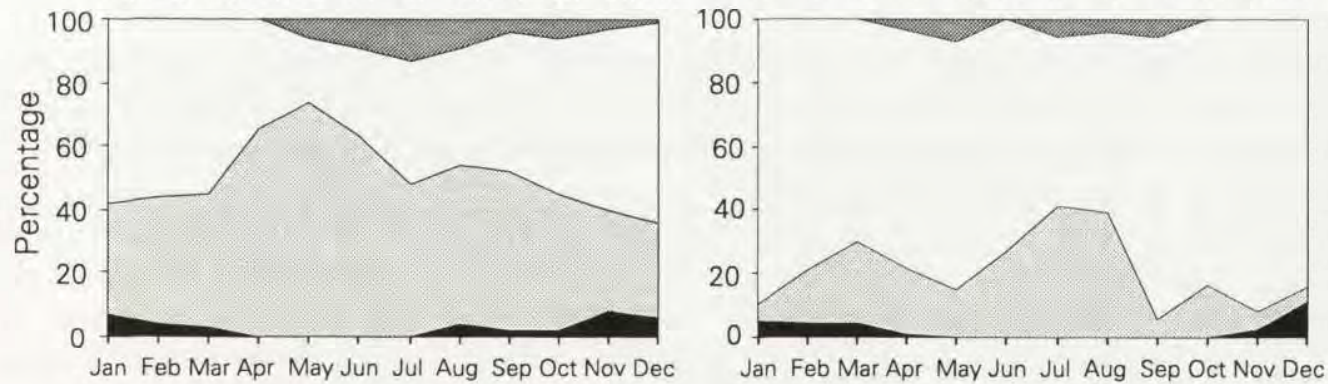

Month

On the ground

Nests

Tree cavities

Branches

Fig. 1. Monthly changes in use of different types of resting sites by male and female pine martens in Białowieża National Park (pooled data from 1991 to 1996), $n$-number of observations in each month. 


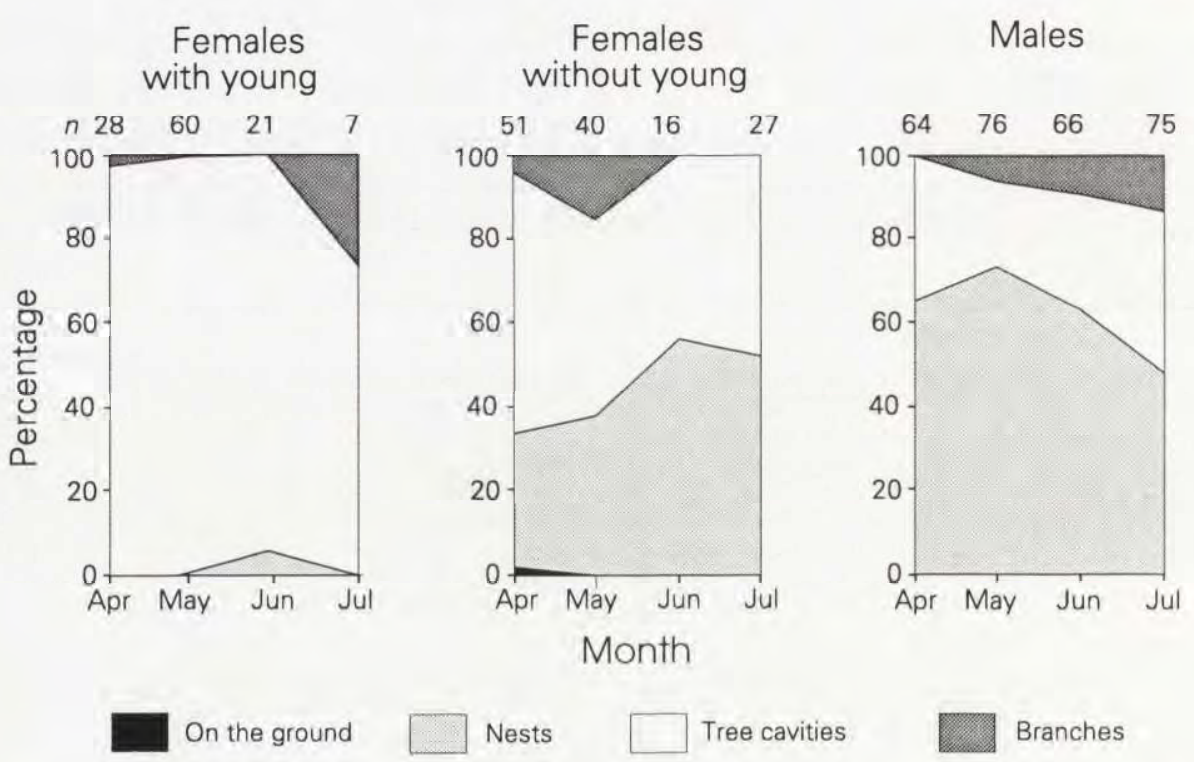

Fig. 2. Use of resting sites in the period of young rearing (April-July) by females with young, females without young and males of pine marten in Bialowieża National Park (data from 1991 to 1996). $n$ number of observations in each month.

$\left(\chi^{2}=144.7\right.$ males vs breeding females, $\chi^{2}=21.5$ males vs non-breeding females, $\mathrm{df}=2, p<0.001$ ).

\section{Influence of climatic factors on selection of resting sites}

Climatic factors influenced the choice of resting sites in various months. For males, temperature was a significant factor in the cold season, from October to May (Fig. 3). Tukey's HSD multiple comparison shows that, in October-January, mean ambient temperature was higher on days when males rested in nests or cavities than on days when they rested on the ground (Fig. 3, Table 2). From February till May on warmer days males rested in nests and on cooler days they rested in cavities. In females, temperature was a significant factor of resting site choice in the cold season (December-March) as well as in summer (June-July). On warmer days, females often rested in nests whereas on cooler days they used cavities (Fig. 3, Table 2).

Air humidity had a strong effect on resting site choice by males in June and July, when mean ambient temperature was highest during the year, and in December-March, in the season of the lowest temperature in the year (Fig. 3). In both cases, males often rested in nests on days when humidity was lower and chose cavities on days when humidity was higher (Fig. 3, Table 2). In April-May, both males and females rested in cavities on more humid days, whereas they used nests or sites on the branches on drier days, but the difference was not significant. 

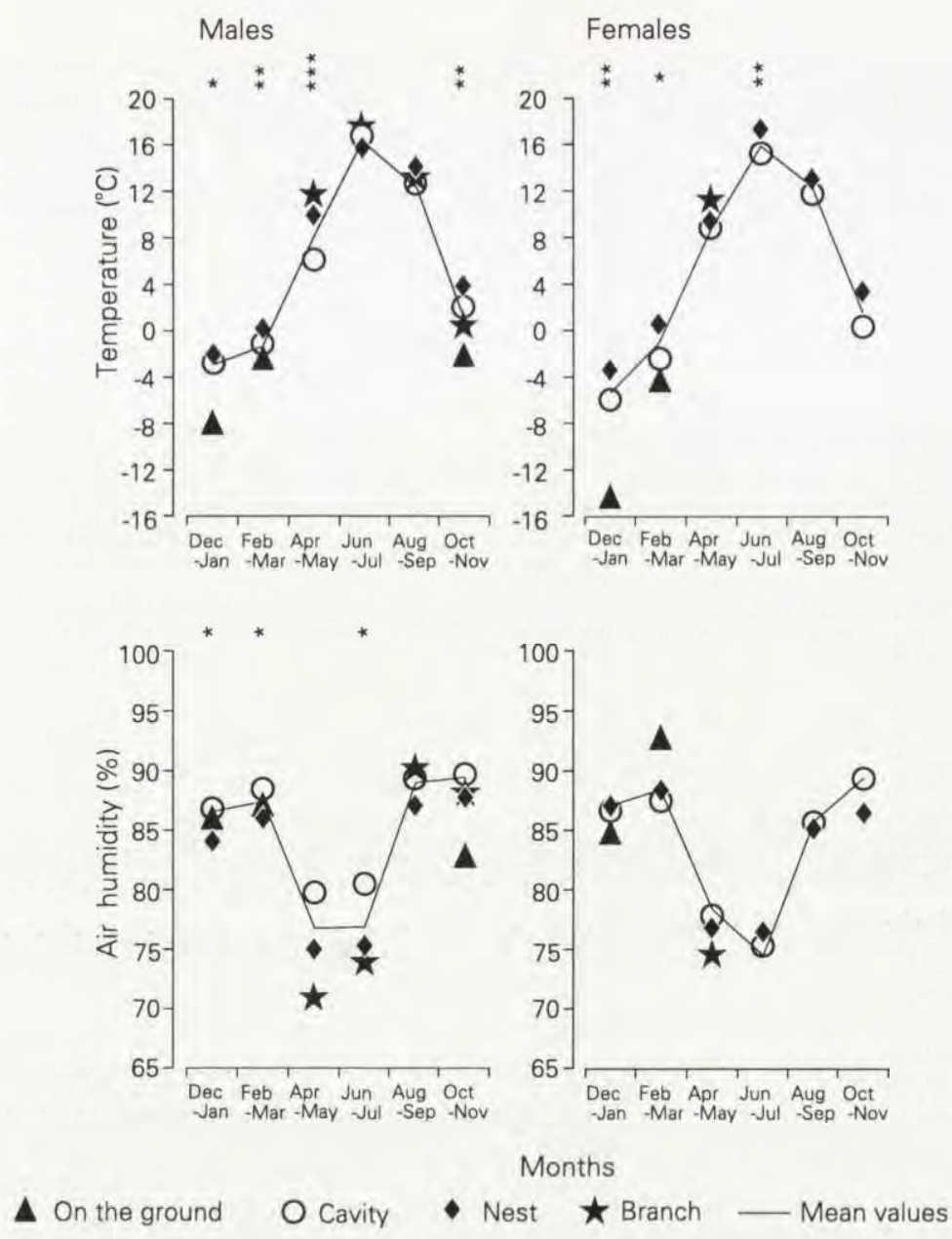

Fig. 3. Comparison of mean values of temperature and humidity on days when pine martens rested in different types of resting sites (symbols) and the mean values of these two weather and variables on all days when martens were found in resting sites (lines) in Bialowieża National Park. Significance of difference between mean values (shown by symbols) for all types of resting sites in each bimonthly period were calculated by ANOVA $\left(* p<0.05,{ }^{* *} p<0.005\right.$, *** $\left.p<0.001\right)$.

Wind speed significantly influenced the choice of resting site by males in February-May (February-March: ANOVA $\mathrm{F}_{2,249}=4.5, p=0.012$; April-May: $\mathrm{F}_{2,137}=4.0, p=0.021$ ). When winds were strong, martens rested in cavities or on the ground and avoided nests (Table 2). For both males and females, snow depth was important at the end of winter (February-March), when snow cover was deep (males: $\mathrm{F}_{2,249}=6.9, p=0.001$; females: $\mathrm{F}_{2,124}=11.2, p<0.001$ ). For males this factor was also significant in early winter (October-November: $\mathrm{F}_{3,200}=3.8, p=0.012$ ). Generally, days when martens chose places on the ground 
Table 2. Pairs of resting site types which significantly differed in terms of weather conditions on the days when pine martens utilised them, tested by Tukey's HSD (Honestly Significant Difference) multiple comparison. All data on temperature and humidity are plotted in Fig. $3 .{ }^{*} p<0.05,{ }^{* *} p<0.005,{ }^{* * *} p<0.001$.

\begin{tabular}{|c|c|c|c|c|}
\hline \multirow{3}{*}{ Bimonthly period } & \multicolumn{4}{|c|}{ Statistically different pairs of resting site types } \\
\hline & \multicolumn{2}{|l|}{ Males } & \multicolumn{2}{|l|}{ Females } \\
\hline & Pair & $p$ & Pair & $p$ \\
\hline \multicolumn{5}{|c|}{ Temperature } \\
\hline \multirow[t]{2}{*}{ December-January } & Cavity-Ground & $* * *$ & Cavity-Ground & $* *$ \\
\hline & Nest-Ground & $* * *$ & Nest-Ground & * \\
\hline February-March & Cavity-Nest & $* *$ & Cavity-Nest & * \\
\hline April-May & Cavity-Nest & $* * *$ & & \\
\hline & Cavity-Branch & * & & \\
\hline June-July & & & Cavity-Nest & $* *$ \\
\hline \multirow[t]{2}{*}{ October-November } & Cavity-Ground & * & & \\
\hline & Nest-Ground & ** & & \\
\hline \multicolumn{5}{|c|}{ Humidity } \\
\hline December-January & Cavity-Nest & * & & \\
\hline February-March & Cavity-Nest & * & & \\
\hline June-July & Cavity-Nest & * & & \\
\hline \multicolumn{5}{|c|}{ Wind speed } \\
\hline \multirow[t]{2}{*}{ February-March } & Cavity-Nest & $*$ & & \\
\hline & Nest-Ground & * & & \\
\hline April-May & Cavity-Nest & * & & \\
\hline \multicolumn{5}{|c|}{ Snow depth } \\
\hline \multirow[t]{2}{*}{ February-March } & Cavity-Nest & $* * *$ & Cavity-Ground & *** \\
\hline & & & Nest-Ground & *** \\
\hline October-November & Nest-Ground & ** & & \\
\hline
\end{tabular}

were characterised by deeper snow cover than days when martens used arboreal sites (Table 2). Climatic factors influenced females' choice of resting sites much weaker than that of males. Female martens rested mostly in cavities, hence variations in their resting site selection was small.

\section{Among-year variation in resting sites use}

The abundance of squirrels and number of their nests varied between the years. From 1991 to 1993 numbers of red squirrels increased (W. Jędrzejewski, unpubl.). After the winter of 1993/94 their number decreased, and in 1994 animals and their tracks were observed very rarely (Fig. 4). In winters 1991/92 and 1992/93 male and female martens used the nests less often than in winters 1993/94 and 1994/95 (males: $G=15.2$, $\mathrm{df}=1, p<0.001$; females: $G=5.1, \mathrm{df}=1, p<0.05$ ) which coincided with the increase in availability of red squirrel nests (Fig. 4). Interestingly enough, the mean temperatures of those four winter did not differ $(t=0.26, \mathrm{df}=603, \mathrm{~ns})$, so 


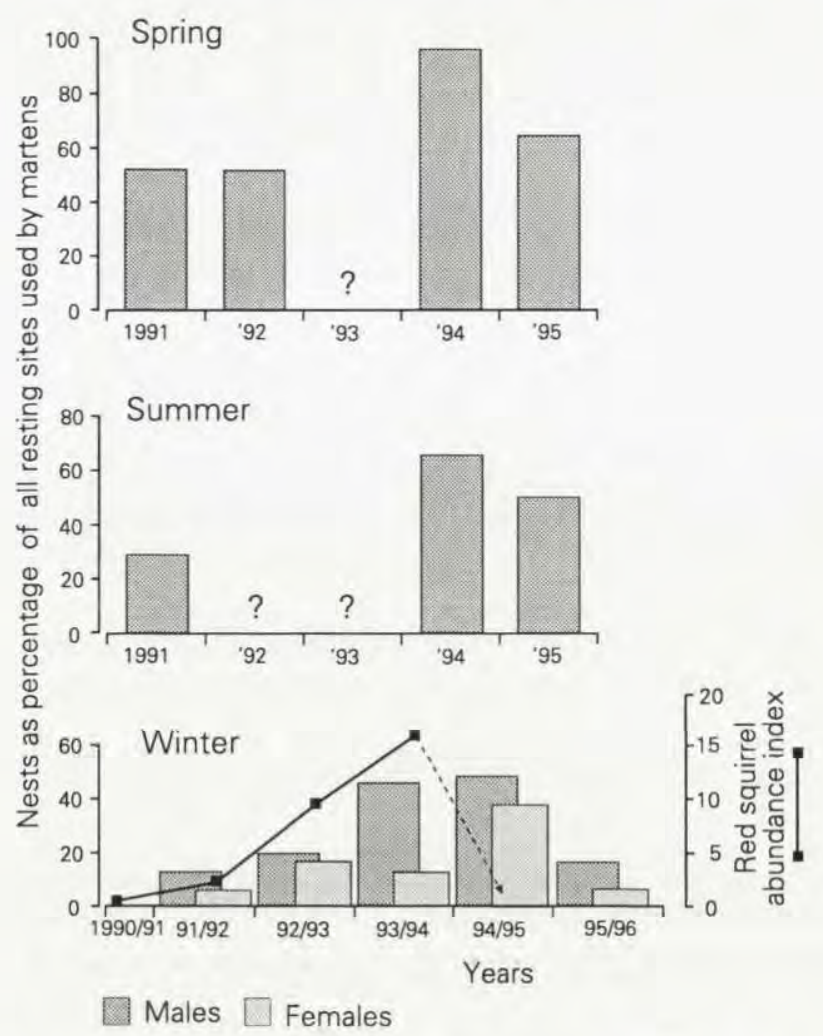

Fig. 4. Frequency of nest use by pine martens in three seasons in different years and red squirrel abundance index estimated as number of tracks per $1 \mathrm{~km}$ (W. Jędrzejewski, unpubl.) in Białowieża National Park. Dashed line indicates an observed (but not censused) decline in red squirrel population, ? - insufficient data.

the observed differences in frequencies of using nests by martens could not have resulted from changes in winter severity. Similar increase in use of nests was observed in spring and summer of 1994, compared with previous years (Fig. 4). After the decline of squirrels (in spring 1995), the percentage of nests among resting sites of male and females martens also decreased.

Temperature influenced among-year variation in the use of resting sites on the ground. During severe winters, martens rested on the ground more often than during mild winters (Fig. 5).

\section{Tree species choice}

Three tree species were used frequently by martens in Białowieża National Park: oak, lime, and spruce (males $-85.7 \%$ and females $-70.6 \%$ of all resting sites). In all seasons, males rested in spruce more often than females ( $G \geq 5.5$, $\mathrm{df}=1, p<0.02$; Table 3 ). Among deciduous trees, males rested mostly in lime and oak $(39.0 \%)$. Other deciduous tree species composed only $14.3 \%$ of all trees 


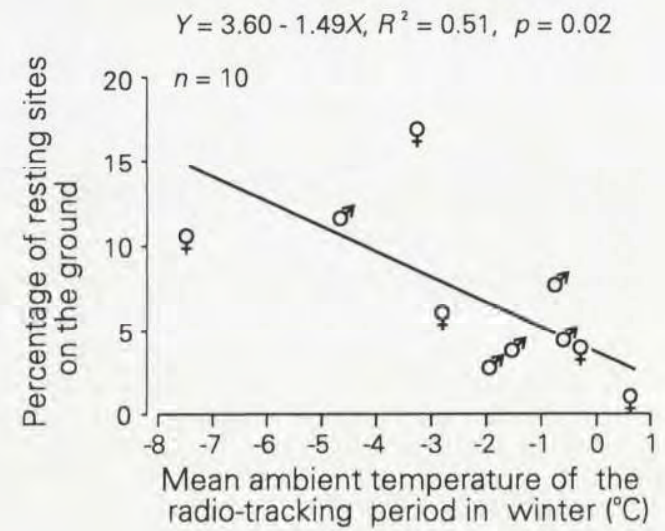

Fig. 5. Resting sites on the ground as percentage of all resting sites used by martens in relation to mean temperature on days when pine martens were radio-tracked in winter. Each point is a mean value for data on a given sex in one season (totally 5 winters).

used by males. Females used oak and lime trees more often $(51.4 \%)$ than males, and also rested in other deciduous trees, especially aspen and ash, more often than males $(27.6 \%, G=4.3, \mathrm{df}=1, p<0.05)$ (Table 3 ). Both males and females rested in hornbeam very rarely. Both sexes used resting sites in lime and oak

Table 3. Tree species used for resting by male and female pine martens in the different seasons and averaged for the whole year in Białowieża National Park, during 1991-1996. W\% - weighted mean percentage (see Table 1 for explanation). ${ }^{a}$ pine, birch, elm, maple.

\begin{tabular}{|c|c|c|c|c|c|c|c|}
\hline \multirow{2}{*}{ Species } & \multicolumn{2}{|c|}{ Spring } & \multicolumn{2}{|c|}{ Summer } & \multicolumn{2}{|c|}{ Autumn-Winter } & \multirow{2}{*}{$\begin{array}{c}\text { Yearly } \\
\text { W\% }\end{array}$} \\
\hline & $n$ & $\%$ & $n$ & $\%$ & $n$ & $\%$ & \\
\hline & & & ales & & & & \\
\hline Spruce & 142 & 63.4 & 133 & 46.2 & 223 & 36.9 & 46.7 \\
\hline Lime & 28 & 12.5 & 54 & 18.8 & 155 & 25.6 & 20.0 \\
\hline Oak & 28 & 12.5 & 68 & 23.6 & 116 & 19.2 & 19.0 \\
\hline Ash & 2 & 0.9 & 3 & 1.0 & 46 & 7.6 & 3.7 \\
\hline Alder & 16 & 7.2 & 5 & 1.7 & 30 & 4.9 & 4.4 \\
\hline Aspen & 0 & 0 & 8 & 2.8 & 20 & 3.3 & 2.3 \\
\hline Hornbeam & 3 & 1.3 & 7 & 2.4 & 4 & 0.7 & 1.4 \\
\hline \multirow[t]{2}{*}{ Other $^{a}$} & 5 & 2.2 & 10 & 3.5 & 11 & 1.8 & 2.5 \\
\hline & & & nales & & & & \\
\hline Spruce & 51 & 20.3 & 28 & 26.4 & 30 & 12.6 & 19.2 \\
\hline Lime & 60 & 23.9 & 30 & 28.3 & 63 & 26.6 & 26.5 \\
\hline Oak & 52 & 20.7 & 26 & 24.5 & 66 & 27.8 & 24.9 \\
\hline Ash & 16 & 6.4 & 8 & 7.6 & 14 & 5.9 & 6.6 \\
\hline Alder & 17 & 6.8 & 3 & 2.8 & 21 & 8.9 & 6.3 \\
\hline Aspen & 41 & 16.3 & 7 & 6.6 & 22 & 9.3 & 10.2 \\
\hline Hornbeam & 8 & 3.2 & 3 & 2.8 & 4 & 1.7 & 2.1 \\
\hline Other $^{a}$ & 6 & 2.4 & 1 & 1.0 & 17 & 7.2 & 3.9 \\
\hline Total & 475 & & 394 & & 842 & & \\
\hline
\end{tabular}


more frequently in winter and summer than in spring. In spring, percentages of spruce and alder increased, especially in males.

While resting in deciduous trees, martens hid in cavities in $90 \%$ of cases recorded (Table 4). When resting on the spruce, where cavities occurred rarely, they used nests or branches. With lime and ash, marten would sometimes use cavities at the base of the tree. Alders tend to grow on small hummocks and hence martens could find burrows among the roots. Martens usually rested in old, thick trees. The minimum dbh of trees where their resting sites were found was $10 \mathrm{~cm}$ for spruce and $35 \mathrm{~cm}$ for hornbeam (Table 5). The average dbh of all trees used by martens was $59 \mathrm{~cm}$.

Table 4. Type of resting sites in the different tree species used by pine martens, during 1991-1996. ${ }^{\mathrm{a}}$ hollows and cavities at the base or root plates of standing trees, ${ }^{\mathrm{b}}$ pine, birch, elm. Data for each species of tree taken as $100 \%$.

\begin{tabular}{|c|c|c|c|c|c|c|c|c|}
\hline \multirow{2}{*}{ Species } & \multicolumn{2}{|c|}{ Cavity } & \multicolumn{2}{|c|}{ Nest } & \multicolumn{2}{|c|}{ Branch } & \multicolumn{2}{|c|}{ On the ground } \\
\hline & $n$ & $\%$ & $n$ & $\%$ & $n$ & $\%$ & $n$ & $\%$ \\
\hline Spruce & 3 & 0.5 & 534 & 93.5 & 34 & 6.0 & 0 & 0 \\
\hline Lime & 363 & 93.3 & 4 & 1.0 & 3 & 0.8 & 19 & 4.9 \\
\hline Oak & 281 & 82.7 & 43 & 12.6 & 11 & 3.2 & 5 & 1.5 \\
\hline Ash & 82 & 93.2 & 0 & 0 & 0 & 0 & 6 & 6.8 \\
\hline Alder & 89 & 96.7 & 0 & 0 & 0 & 0 & 3 & 3.3 \\
\hline Aspen & 93 & 95.8 & 0 & 0 & 2 & 2.1 & 2 & 2.1 \\
\hline Hornbeam & 20 & 80.0 & 4 & 16.0 & 1 & 4.0 & 0 & 0 \\
\hline Maple & 16 & 59.3 & 8 & 29.6 & 2 & 7.4 & 1 & 3.7 \\
\hline Other $^{b}$ & 17 & & 0 & & 1 & & 0 & \\
\hline
\end{tabular}

Table 5. Diameter at breast height (dbh) of different tree species used by pine martens for resting sites in BNP. $n$-number of measured trees.

\begin{tabular}{lcccl}
\hline \multirow{2}{*}{ Species } & $n$ & \multicolumn{3}{c}{ Tree dbh $(\mathrm{cm})$} \\
\cline { 3 - 5 } & & Mean & SD & Range \\
\hline Spruce & 147 & 40.0 & 15.5 & $10-90$ \\
Lime & 59 & 74.6 & 17.7 & $40-110$ \\
Oak & 82 & 85.6 & 22.7 & $44-150$ \\
Ash & 9 & 58.0 & 10.6 & $44-75$ \\
Alder & 14 & 54.0 & 11.1 & $33-75$ \\
Aspen & 14 & 56.3 & 14.3 & $40-81$ \\
Hornbeam & 7 & 44.2 & 10.2 & $35-60$ \\
Maple & 8 & 57.0 & 13.3 & $40-80$ \\
Pine & 8 & 62.9 & 9.3 & $51-80$ \\
All trees & 349 & 58.9 & 26.2 & $10-150$ \\
\hline
\end{tabular}


Comparison of resting tree selection with tree composition in the study area (landscape scale) shows that martens selected limes and oaks, and avoided hornbeams (Fig. 6). In all seasons, females avoided spruce more strongly than did males (Fig. 6). At the home range scale, in all seasons, martens strongly selected limes and avoided hornbeams (Fig. 6). Selection of other tree species (oak, ash and alder) changed with seasons. Ash and alder were avoided in summer, spruce in autumn-winter.

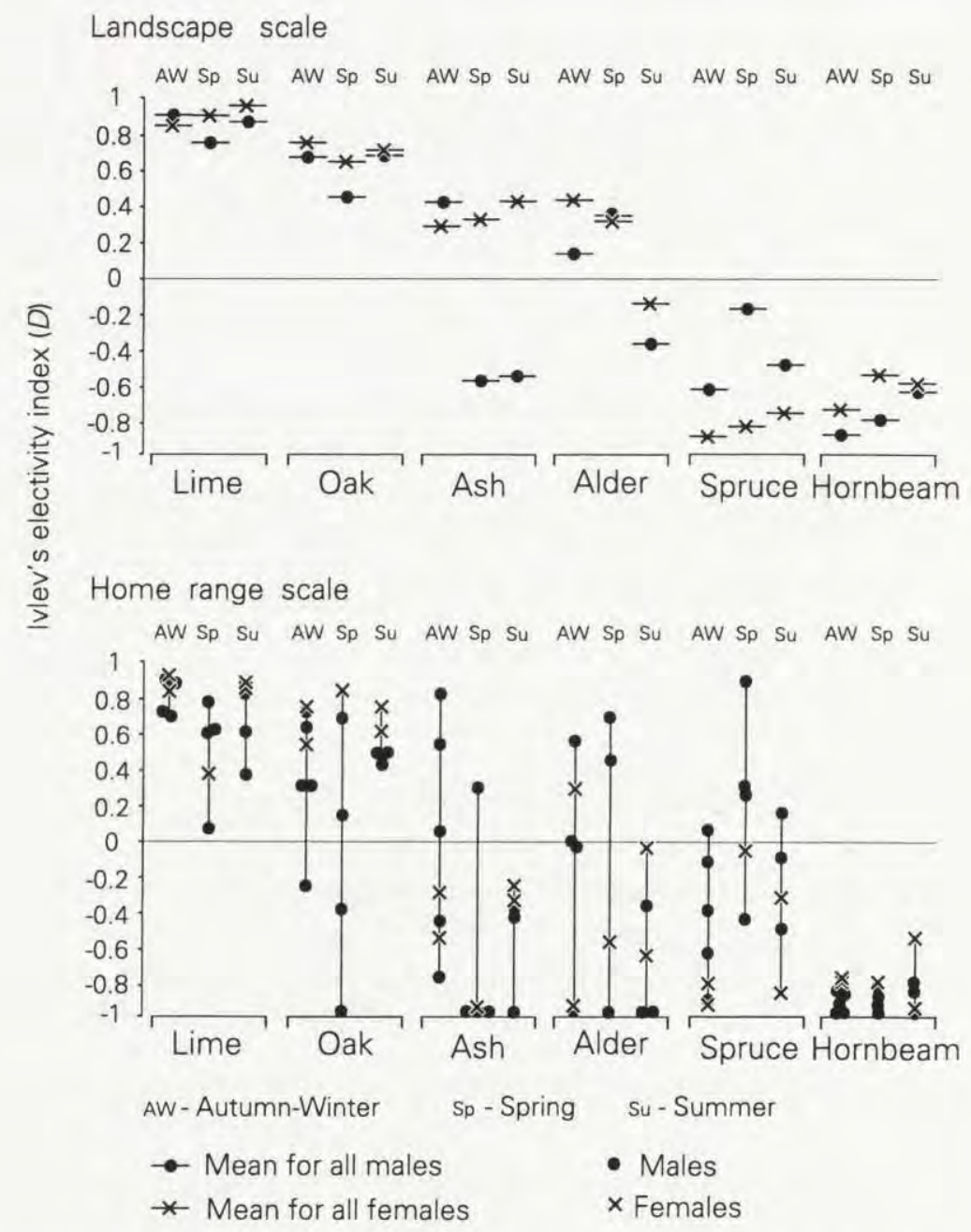

Fig. 6. Ivlev's electivity index $(D)$ for the choice of tree species for location of resting sites by pine martens. $D=(r-p) /(r+p-2 r p)$, where $r$ is a fraction of a given tree species among sample of available trees, and $p$ is a fraction of a given tree species in the trees used by pine martens. $D$ varies from -1 (complete avoidance), to 0 (random usage) to 1 (the strongest positive selection). Landscape scale (upper panel): index calculated for the whole Białowieża National Park. Home range scale (lower panel): index calculated for home ranges of individual pine martens. 


\section{Discussion}

Influence of climatic factors on selection of resting sites

The choice of resting site types is mainly influenced by two factors: (1) energy budget, and (2) predation risk of the animals (Buskirk 1984, Buskirk et al. 1988). Thus far, many results suggest that the energetic factors affect resting site choice only in winter. However, this paper shows that this factor is important throughout the year. In the year three seasons were distinguished: autumn-winter - with temperatures low all day, spring - with temperatures low at night and relatively high in daylight hours, and summer - when temperatures are high all day. During these three seasons different factors affected marten's choice of resting site. Pine marten, probably like American marten Martes americana, has a relatively high lower critical temperature (for American marten $16^{\circ} \mathrm{C}$; Buskirk et al. 1988). Because of their elongated shape, in winter, thermoregulation costs are considerably higher in martens than in other mammals of similar size (Brown and Lasiewski 1972, Iversen 1972). This is why martens pay high energetic costs during winter. Therefore, the selection of better insulated resting sites may influence the survival of martens during this period. At the resting site, heat loss depends on (1) conductance of the air in the resting site between the martens' fur and the den walls, and (2) conductance of resting site's walls (Thorkelson and Maxwell 1974). Total heat loss increases approximately linearly as ambient temperature decreases (Thorkelson and Maxwell 1974). Ambient temperature was an often mentioned factor influencing resting or den site choice by different species (Waechter 1975, Weber 1985, 1989, Rabinowitz and Pelton 1986, Buskirk et al. 1989, Marchesi 1989, Taylor and Buskirk 1994, Brainerd et al. 1995). In this study, ambient temperatures were important between October and May. But not only are differences between the temperature of the animal's body and the air important. The coefficient of air conductance must be also considered. Air conductance coefficient increases with the increase in humidity. This is why heat losses increase with increased humidity and why this factor had an important role in resting site choice by martens in winter.

The conductance of the resting site's walls is influenced by type and thickness of the wall. I hypothesize that this is why in winter martens chose the cavities (with wood walls) more frequently than squirrel nests (with grass and stick walls) and preferred deciduous trees, especially large diameter limes and oaks. Conductance is also influenced by snow depth, especially when martens rest $0-0.5 \mathrm{~m}$ above the ground. The snow cover can increase insulation of the resting site walls. This factor probably influenced resting site choice when temperature was low and snow cover was relatively deep. Martens did not rest under snow in BNP, as did pine martens in other regions (Nasimovich 1948, Pulliainen 1981) and as did American martens in winter (Buskirk et al. 1989, Martin and Barrett 1991).

In spring, temperature quickly increases in morning. However, temperatures in cavities and at places on the ground increase more slowly than in open nests 
or on branches in high tree tops where solar radiation is much stronger (Stains 1961). In that season males chose nests, particularly in spruce, where squirrels often built their dreys. Many nests, where the males rested, were missing the top part. Females with the young, chose more secure sites in cavities, where probably also heat losses were smaller on cold spring nights when cubs often stayed alone (A. Zalewski, unpubl.). In BNP also wind speed influenced martens' choice of resting site during spring and some researchers have mentioned its importance for American martens, too (Taylor and Buskirk 1994).

In summer, when temperatures are high, animals need to lose metabolic heat produced by body (especially by brain) (Caputa 1982). The problem with metabolic heat loss in high temperatures is that it increases with an increase of body mass (and brain size). Animals heavier than $0.5 \mathrm{~kg}$ need special processes to lose the metabolic heat produced in the brain (Caputa 1982). Hyperthermia is especially dangerous for mammals because their body temperature (for marten $39.2^{\circ} \mathrm{C}$; Tumanov 1993) is very close to the temperature at which the brain would be damaged (about $41^{\circ} \mathrm{C}$; Caputa 1982). It is probable that martens, like other Carnivora, are able to reduce body temperature by evaporation at nasal mucosa (Baker 1979). This process is very effective, but only when the humidity is low, and its effectiveness decreases with an increase in humidity. Therefore, in summer, in high temperature and high humidity, males of pine marten chose places deep in the cavity where temperature is lower than outside (Rabinowitz and Pelton 1986). This situation occurred in June and especially in July, when use of cavities increased. In Scandinavia, percentage of resting places on the ground also increased in higher temperature (Brainerd et al. 1995). This result suggests that also in Scandinavia martens look for colder underground resting sites in higher temperature in summer. Humidity affects the resting site choice in cold and warm seasons but in each of them it influences different physiological processes.

\section{Geographical pattern of resting site choice and predation risk}

Two main factors change in marten range with geographical gradients: (1) availability of different types of resting sites (coniferous versus deciduous forests) and (2) climate. Boreal forests are composed mainly of coniferous trees, with low numbers of cavities (Newton 1994) and fewer woodpecker species than in deciduous forests (Angelstam and Mikusiński 1994). Moreover, northern winters are much more severe. Therefore, in boreal coniferous forests in north Scandinavia, $90 \%$ of marten resting sites were on the ground (Fig. 7 , points 2,3 ), because (1) this type of resting site is much warmer than arboreal resting sites (Rabinowitz and Pelton 1986) and/or (2) martens did not have access to warm arboreal places (cavities). In southern Scandinavia, covered with coniferous forests, where winters are relatively mild, martens still rested on the ground but the percentage of nest sites increased (Fig 7, point 1). Martens probably choose places where predation risk is lower (ie nest), but because winter temperature is low, they chose underground dens (there are no 'warm' cavities available). In mixed forests 


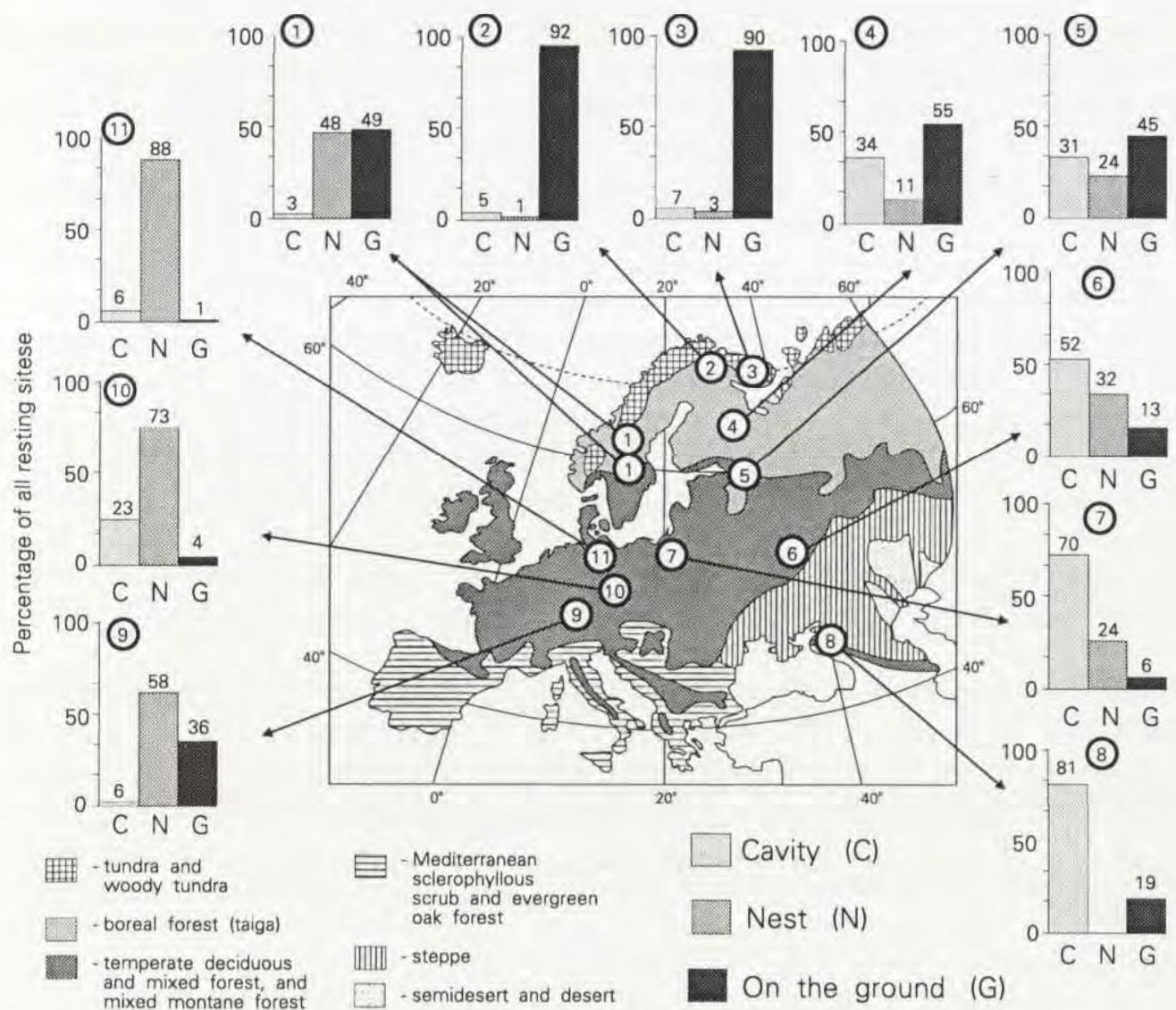

Fig. 7. Use of resting sites of different types (in \%) by pine martens in different biomes of Europe in winter. Numbers in circles are sources: (1) Brainerd et al. (1995), $n=194$; (2) Pulliainen (1981), $n=$ 666; (3) Nasimovich (1948), $n=39$; (4) Danilov and Tumanov (1976), $n=56$; (5) Novikov et al. (1970), $n=40$; (6) Voronin (1979), $n=89$; (7) this study, $n=850$; (8) Ryabov (1959), $n=16$; (9) Marchesi (1989, and pers. comm.), $n=173$; (10) Ebersbach et al. (1995), $n=398$; (11) Stier (1996), $n=434$. $n$-sample size. In source (10) and (11) data are from the whole year.

(coniferous and deciduous), the percentage of tree cavities among resting sites increased (Fig. 7 , points 5,6 ). This means that martens choose safe and warm resting sites. Cavities were very frequently used in deciduous forest in Białowieża National Park (Fig. 7, point 7). In western Europe, where winters are milder, martens often rested in nests and the percentage of resting sites on the ground was relatively low (Fig. 7 , points 10, 11).

This comparison shows that different factors affect the resting site choice in different regions. However, the primary factor for martens is to reduce the heat loss during cold winters (by choosing warmer resting sites, often on the ground or, if available, in a cavity). Secondly, martens have to feel secure (by the choice 
of an arboreal resting site). In the geographic scale, percentage of nests among marten resting sites was positively correlated with winter temperature (in December-March; $R^{2}=0.66, p=0.015, n=8$ localities; climate data from Lebedeva et al. 1979, and Brockhaus 1983). Percentage of resting sites on the ground was positively correlated with number of days with snow cover $\left(R^{2}=0.66\right.$, $p=0.015, n=8$ localities).

This comparison also suggests that, in the northern part of its range, marten could also be affected by predation. Indeed, in Scandinavia for example, martens killed by red foxes Vulpes vulpes have been reported (Pulliainen 1981, Lindström et al. 1995) and in some cases foxes killed martens in their underground den. Also, the marten population has increased in Scandinavia since 1985, which coincides with a decrease in the red fox population due to sarcoptic mange (Storch et al. 1990). Food competition and habitat segregation between these two predators did not influence the increase of marten density (Storch et al. 1990). Some authors have suggested that the fox limited the marten population in Sweden (Lindström et al. 1995) but in the BNP deciduous forest, observations of martens killed by foxes have been reported neither during the radiotracking of martens nor in 1985-1990 when $80 \mathrm{~km}$ of snow tracking of foxes (Jędrzejewski and Jędrzejewska 1992 ) and $64 \mathrm{~km}$ of snow tracking of pine martens (Jędrzejewski et al. 1993) were carried out. In other regions of Poland no records of martens killed by foxes have been recorded (ca $800 \mathrm{~km}$ of snow tracking of foxes; J. Goszczyński, pers. comm.). Thus, it is possible that in the northern part of the martens' range, fox and other predators limit the marten population because marten cannot choose safe arboreal resting sites (either because there are not enough cavities or because the temperatures are too low).

Acknowledgements: I wish to thank the technician staff of MRI (G. Bujko, K. Zub), students of Farnborough College of Technology (England) and Earthwatch Research Corps for their field work. The late $\mathrm{Mr}$ L. Siemieniuk provided invaluable help with collecting meteorological data. I am grateful to Dr W. Jędrzejewski for granting me his unpublished data. I am indebted to Professors J. Goszczyński, Z. Pucek, Drs B. Jędrzejewska and L. Rychlik for their criticism of the manuscript. The study was partly supported by the grant KBN 6 P205 08006 . The author was a recipient of the National Fellowship '97 from the Foundation for Polish Science.

\section{References}

Angelstam P. and Mikusiński G. 1994. Woodpecker assemblages in natural and managed boreal and hemiboreal forest - a review. Annales Zoologici Fennici 31: 157-172.

Baker M. A. 1979. A brain-cooling system in mammals. Scientific American 240: 130-138.

Baranauskas K. 1990. [Seasonal dynamic of artificial resting sites use by pine marten]. [In: Mlekopitayushchie v kul'turnom landshafte Litvy. P. Bluzma, ed]. Mokslos, Vilnus: 117-121. [In Russian]

Baudvin H., Dessolin J.-L. and Riols C. 1985. L'utilisation par la martre (Martes martes) des nichoirs a chouettes dans quelques forets Bourguignonnes. Ciconia 9: 61-104.

Brainerd S. M., Helldin J. O., Lindström E. R., Rolstad E., Rolstad J. and Storch I. 1995. Pine marten (Martes martes) selection of resting and denning sites in Scandinavian managed forests. Annales Zoologici Fennici 32: 151-157. 
Brockhaus F. A. 1983. Länder und Klima. Europa, UdSSR. Brockhaus Verlag, Wiesbaden: 1-240.

Brown J. H. and Lasiewski R. C. 1972. Metabolism of weasels: The cost of being long and thin. Ecology 53: 939-943.

Buskirk S. W. 1984. Seasonal use of resting sites by marten in South-Central Alaska, Journal of Wildlife Management 48: 950-953.

Buskirk S. W., Forrest S. C., Raphael M. G. and Harlow H. J. 1989. Winter resting site ecology of marten in the Central Rocky Mountains. Journal of Wildlife Management 53: 191-196.

Buskirk S. W., Harlow H. J. and Forrest S. C. 1988. Temperature regulation in American marten (Martes americana) in winter. National Geographic Research 4(2): 208-218.

Buskirk S. W. and Harlow H. J. 1989. Body-fat dynamics of the American marten (Martes americana) in winter. Journal of Mammalogy 70: 191-193.

Corbert G. B. and Harris S. 1991. The handbook of British mammals. Blackwell Science, Oxford: 1-588.

Caputa M. 1982. The mechanisms of brain protection against overheating in human and same other species of mammals. Uniwersytet Mikołaja Kopernika, Torun: 1-123. [In Polish with English summaryl

Danilov P. I. and Tumanov I. L. 1976. [Mustelids in north-eastern USSR]. Nauka, Leningrad: 1-256. [In Russian]

Ebersbach H., Hofmann T. and Stubbe M. 1995. Do resting sites of martens reflect animals' home ranges? Abstracts of 2nd International Martes Symposium, Edmonton, Alberta, 12-16 August 1995, p. 17.

Faliński J. B. 1986. Vegetation dynamics in temperate lowland primeval forest. Dr. W. Junk Publishers, Dordrecht: 1-537.

Forest Management Plan of the Białowieża National Park (strict reserve, buffer zone, Palace Park) for the period 1 January 1991 - 31 December 2010. 1992. Forest Management and Geodesy Office, Białystok Department, Białystok. [In Polish]

Grakov N. N. 1981. [The pine marten]. Nauka, Moskva: 1-109. [In Russian]

Iversen J. A. 1972. Basal energy metabolism of mustelids. Journal of Comparative Physiology 81: 341-344.

Jacobs J. 1974. Quantitative measurements of food selection; a modification of the forage ratio and Ivlev's Electivity index. Oecologia 14: 413-417.

Jędrzejewski W. and Jędrzejewska B. 1992. Foraging and diet of the red fox Vulpes vulpes in relation to variable food resources in Białowieża National Park, Poland. Ecography 15: 212-220.

Jędrzejewski W., Zalewski A. and Jędrzejewska B. 1993. Foraging by pine marten Martes martes in relation to food resources in Białowieża National Park, Poland. Acta Theriologica 38: 405-426.

Korhonen H., Pyyvaara P. and Niemelä P. 1995. Energy economy and activity in farmed pine martens (Martes martes). Scientifur 19: 270-276.

Lebedeva A. N., Borushko I. S. and Egorovoï A. Yu. 1979. [Climate reference book of West Europel. Gidrometeoizdat, Leningrad: 1-679. [In Russian]

Lindström E. R., Brainerd S. M., Helldin J. O. and Overskaug K. 1995. Pine marten - red fox interactions: A case of intraguild predation? Annales Zoologici Fennici 32: 123-130.

Marchesi P. 1989. Ecologie et comportement de la martre (Martes martes L.) dans le Jura Suisse. Ph D thesis, Universite de Neuchâtel, Institute de Zoologie, Neuchâtel: 1-185.

Martin S. K. and Barrett R. H. 1991. Resting site selection by marten at Sagehen Creek, California. Northwestern Naturalist 72: 37-42.

Nasimovich A. A. 1948. [Ecology of the pine marten]. Trudy Laplandskogo zapovednika 3: 81-106. [In Russian]

Newton I. 1994. The role of nest sites in limiting the numbers of hole-nesting birds: a review. Biological Conservation 70: 265-276.

Novikov G. A., Airapet'yants A. E., Pukinskiï Y. B., Strelkov P. P. and Timofeeva E. K. 1970. [Animals of Leningrad district (fauna, ecology and management)]. Nauka, Leningrad: 1-360. [In Russian] 
Ocetkiewicz J. 1973. [Results of pine marten (Martes martes L. 1758) breeding in captivity]. Wydawnictwa Własne Instytutu Zootechniki 351: 1-48. [In Polish with English summary]

Okarma H. 1995. The trophic ecology of wolves and their predatory role in ungulate communities of forest ecosystems in Europe. Acta Theriologica 40: 335-386.

Okarma H., Jędrzejewski W., Schmidt K., Kowalczyk R. and Jędrzejewska B. 1997. Predation of Eurasian lynx on roe deer and red deer in Białowieża Primeval Forest, Poland. Acta Theriologica 42: $203-224$.

Olszewski J. L. 1986. The role of forest ecosystems in modifying local climate of the Białowieża Primeval Forest, as revealed by air temperature characteristics. Wydawnictwo PAN (Prace habilitacyjne), Ossolineum, Wrocław: 1-222. [In Polish with English summary]

Pulliainen E. 1981. Winter habitat selection, home-range, and movements of the Pine marten (Martes martes) in Finnish Lapland Forest. [In: Worldwide Furbearer Conference Proceedings. J. A. Chapman and D. Pursley, eds]. August 3-11, 1980, Frostburg, Maryland, USA: 1068-1087.

Rabinowitz A. R. and Pelton M. R. 1986. Day-bed use by raccoons. Journal of Mammalogy 67: 766-769.

Ryabov L. S. 1959. [Kavkaz pine and stone martens in Krasnodarsk region]. Trudy Kavkazskogo Gosudarstvennogo Zapovednika 5: 62-94. [In Russian]

Scholander P. F., Walters V. and Hock R. 1950. Body insulation of some arctic and tropical mammals and birds. Biological Bulletin 99: 225-236.

Sokołowski W. A. 1993. Phytosociological characteristics of forest communities in the Białowieża National Park. Parki Narodowe i Rezerwaty Przyrody 12: 5-190. [In Polish with English summary]

Stains H. J. 1961. Comparison of temperatures inside and outside two tree dens used by raccoons. Ecology 42: 410-413.

Stier N. 1996. Home-ranges, resting places and habitat selection of the pine marten (Martes martes L., 1758) in Mecklenburg. Varhandlungen der Gesellschaft für Ökologie 26: 339-344.

Storch I., Lindström E. R. and de Jounge J. 1990. Diet and habitat selection of the pine marten in relation to competition with the red fox. Acta Theriologica 35: 311-320.

Taylor S. L. and Buskirk S. W. 1994. Forest microenvironments and resting energetics of the American marten Martes americana. Ecography 17: 249-256.

Thompson I. D. and Colgan P. W. 1991. Optimal foraging by martens Marten americana: the role of large prey in winter. [In: Global trends in wildlife management. B. Bobek, K. Perzanowski and W. Regelin, eds]. Świat Press, Kraków, Warszawa: 173-176.

Thorkelson J. and Maxwell R. K. 1974. Design and testing of a heat transfer model of a Raccoon (Procyon lotor) in a closed tree den. Ecology 55: 29-39.

Tumanov I. L. 1993. [Adaptative features of mammals from the mustelid family, Mammalia, Mustelidae]. Ph D thesis, Sankt-Petersburgskoii Gosudarstvennyï Universitet, Sankt-Petersburg: 1-49. [In Russian]

Voronin A. A. 1979. [Ecology of the pine marten in south Niechernozeme]. [In: Ekologitseskie osnovy okhrany i ratsional'nogo ispol'zovaniya khishchnykh mlekopitayushchikh. V. E. S. Sokolov, ed]. Nauka, Moskva: 310-311. [In Russian]

Waechter A. 1975. Ecologie de la fouine en Alsace. Revue D'Ecologie - La Terre et La Vie 29: 399-457.

Weber D. 1985. Den use by foxes (Vulpes vulpes) and its function. Zeitschrift für Säugetierkunde 50: $356-368$.

Weber D. 1989. The ecological significance of resting sites and the seasonal habitat change in polecats (Mustela putorius). Journal of Zoology, London 217: 629-638.

Zalewski A. 1997. Patterns of resting site use by pine marten, Martes martes, in Białowieża National Park (Poland). Acta Theriologica 42: 153-168.

Zielinski W. J., Spencer W. D. and Barrett R. H. 1983. Relationship between food habits and activity patterns of pine martens. Journal of Mammalogy 64: 387-396.

Received 28 October 1996, accepted 20 June 1997. 